\title{
INFLUENCE OF ULTRASOUND ON STORAGE TIMES OF FERMENTED CABBAGE
}

\author{
Shagen Gasparyan, Irina Gasparyan \\ Russian Timiryazev State Agrarian University, Russia \\ schagen2010@yandex.ru, irina150170@yandex.ru
}

\begin{abstract}
Fermented cabbage is a popular product in the world. There are many recipes for making fermented cabbage. It is produced in a microbiological way and unfortunately has a limited shelf life in the finished form. In order to reduce the number of microorganisms in the product and achieve an increase in shelf life, a study was conducted using ultrasonic treatment of fermented cabbage. The aim of the research was to determine the technical and technological parameters of ultrasonic treatment of fermented cabbage with different intensities and temporary conditions to increase the shelf life. The studies were conducted in 2018/2019 in the Russian State Agrarian University - Moscow Timiryazev Agricultural Academy in the laboratory of processing of fruit and vegetable production. For fermentation we used white cabbage F1 Valentine hybrid, which meets the requirements for raw materials. It was prepared according to the technological instructions that meet the requirements of the normative document GOST 34220-2017. The experience is two-factor: the first factor was the study of the influence of changes in the frequency of oscillations of ultrasound $(20 ; 30 ; 40 ; 50 \mathrm{kHz})$, the second factor was the study of the influence of the time interval $(2 ; 4 ; 6 ; 8 ; 10 \mathrm{~min}$.). Ultrasonic processing was carried out on the RPM-2/12-N installation. The processing intensity was constant and amounted to $10^{4} \mathrm{~W} \cdot \mathrm{m}^{-2}$. As a result of the studies, it was found that the processing regimes are optimal in which the effect of ultrasound does not soften the cabbage, but helps increase the shelf life due to the inhibitory effect of fermented products on the microflora, primarily lactic acid bacteria. Such modes are a frequency of $30 \mathrm{kHz}$ with a duration of ultrasonic processing of 8 minutes. So, the tasting score on the 26th day of storage in this mode was 4.6 points, which is significantly higher than with other processing parameters. The acid indicator of fermented cabbage in this mode on the 26th day had a value of $1.1 \%$, which fully corresponded to the requirements of the standard.
\end{abstract}

Key words: cabbage, ultrasound, frequency, duration.

\section{Introduction}

Fermented cabbage is a very popular product not only in Russia but also in the world. For many people living in the EU countries, fermented cabbage is an indispensable ingredient for making dishes. This product is very fond for Germans, Poles, Czechs and other peoples. It is served in Germany in beer bars with sausages, bake pies and pies, cook borscht, cabbage soup, etc [1].

There are many recipes for fermented cabbage. Different options with the use of vegetable and fruit ingredients, spices and spices forming the unique organoleptic qualities of fermented cabbage products are determined by national food traditions and people's culinary preferences [2].

Despite the large assortment variety of fermented cabbage, the technology for preparing the product is based on a microbiological process, mainly lactic acid fermentation. As a result of the vital activity of various microorganisms, primarily lactic acid bacteria, the biochemical composition of the feedstock is completely changed. The unique organoleptic qualities of fermented cabbage are the result of the activity of that epiphytic microflora, which spontaneously arises in a particular batch of the manufactured product. When organizing the technological work of picking, during the fermentation period, favorable conditions are created for the reproduction and development of lactic acid microorganisms [3].

Ready fermented cabbage has a limited shelf life, especially after packaging the product in consumer containers. It is possible to increase the shelf life using various methods: conservation fermented cabbage, pasteurization, the use of preservatives, as well as storage at low temperatures. Each of these methods has advantages, however, there are certain side effects that degrade the quality of fermented cabbage. In order to reduce the number of microorganisms in the product and achieve an increase in the shelf life, a study was conducted using ultrasonic treatment of fermented cabbage [4].

The aim of the research was to determine the technical and technological parameters of ultrasonic treatment of fermented cabbage with different intensities and temporary conditions to increase the shelf life. 


\section{Materials and methods}

The studies were conducted in 2018/2019 in the Russian State Agrarian University - Moscow Timiryazev Agricultural Academy in the laboratory of processing of fruit and vegetable production. White cabbage hybrid F1 Valentine was used for fermentation that meets the requirements for raw materials [5].

The object of research was fermented cabbage. It was prepared according to the technological instructions that meet the requirements of the regulatory document GOST 34220-2017 Salted and pickled vegetables. General specifications. Organoleptic and physico-chemical indicators were determined according to GOST 8756.1. Fermented cabbage met the following requirements: cabbage - evenly chopped in strips of $2 \mathrm{~mm}$ wide, without large pieces of cabbage stalk and pieces of leaves. To taste - characteristic of pickled vegetables with a brackish-sour taste; by smell - characteristic of fermented cabbage; the color of cabbage is light straw with a yellowish tinge. The texture is crispy when cracked. The brine is unclear, with a pleasant aroma, a more pronounced brackish-sour taste. According to the physicochemical requirements, fermented cabbage had the following indicators: mass fraction of cabbage $88 \%$ and mass fraction of brine $12 \%$. Mass fraction of chlorides in brine was determined according to GOST 26186 and amounted to $1.5 \%$; the mass fraction of titratable brine acids was based on GOST ISO 750 and had an indication of $0.7 \%$.

Microbiological indicators were determined according to GOST 31904 and met all the requirements. The content of toxic elements in fermented cabbage was determined according to GOST. The results obtained did not exceed the level of permitted indicators.

The experience is two-factor: the first factor was the study of the influence of changes in the frequency of oscillations of ultrasound $(20 ; 30 ; 40 ; 50 \mathrm{kHz})$, the second factor was the study of the influence of the time interval $(2 ; 4 ; 6 ; 8 ; 10 \mathrm{~min}$.). Ultrasonic processing was carried out on the RPM2/12-N installation [6].

The processing intensity was constant and amounted to $10^{4} \mathrm{~W} / \mathrm{m} 2$. Samples of sauerkraut were processed and then the products were loaded into consumer containers (diameters: lower $113 \mathrm{~mm}$, upper $133 \mathrm{~mm}$; height $60 \mathrm{~mm}$, volume $0.5 \mathrm{l}$ ). The experimental variants were sent to a refrigerator with a temperature of +2 to $+6^{\circ} \mathrm{C}$. The control version was stored at a similar temperature regime, but was not sonicated.

\section{Research results}

High-quality fermented cabbage should have a pleasant aroma, slightly pronounced sweet and sour taste. Also, the cabbage must be crispy in consistency. These organoleptic characteristics are characteristic of freshly prepared fermented cabbage [5].

However, during storage, these qualities deteriorate and acidity increases, which does not very well affect the commodity quality of the products. The consistency also worsens, the product becomes soft, the visual appeal is lost. Through the use of ultrasound technology, it was possible to maintain organoleptic characteristics for a longer time [7-8].

During the research, the optimal treatment modes for fermented cabbage with ultrasound were selected in different versions $(20.0 ; 30.0 ; 40.0 ; 50.0 \mathrm{kHz})$ with a processing time of $2 ; 4 ; 6 ; 8 ; 10$ minutes. As a control, a sample was taken without treatment. Tasting assessment and determination of acidity was carried out on 14; 18;22; 26 days of storage (table 1). This assessment was carried out on a 5-point scale, by such indicators as taste, aroma, texture, appearance, typicality [5].

The research work was based on the results of organoleptic assessment and dynamics of changes in acidity.

According to the results of organoleptic evaluation, fermented cabbage of the control variant on the 14th day of storage under conditions of $+4+6^{\circ} \mathrm{C}$, which corresponded to the temperature regime of the shop windows, received a satisfactory rating (3.6 points) during tasting [5]. There was a softening of the consistency of cabbage, the products were acidic. Her external attractiveness was low. On the 26th day of storage, the overall assessment of organoleptic indicators worsened by half and amounted to 1.8 points. A pronounced sour taste was recorded, the product became flabby, when cracked, it did not crunch, the pleasant aroma previously inherent in fermented cabbage was absent. This is because the sugars are completely fermented. By smell it was possible to judge that there was 
alcohol and acetic fermentation. As a result of this, fermented cabbage not only lost its commodity qualities, but also became unusable [9].

Table 1

Organoleptic evaluation of fermented cabbage after storage at different times with ultrasound treatment of different intensities

\begin{tabular}{|c|c|c|c|c|c|c|c|}
\hline \multirow{2}{*}{$\begin{array}{c}\text { Range of } \\
\text { ultrasonic } \\
\text { processing, } \mathrm{kHz}\end{array}$} & \multirow{2}{*}{$\begin{array}{c}\text { Term of storage in } \\
\text { consumer } \\
\text { packaging, day }\end{array}$} & \multicolumn{6}{|c|}{ Processing time, minutes } \\
\hline & & 0 & 2.0 & 4.0 & 6.0 & 8.0 & 10.0 \\
\hline \multirow{4}{*}{$\begin{array}{l}\text { Controlwithout } \\
\text { processing }\end{array}$} & 14 & 3.6 & - & - & - & - & - \\
\hline & 18 & 2.8 & - & - & - & - & - \\
\hline & 22 & 2.2 & - & - & - & - & - \\
\hline & 26 & 1.8 & - & - & - & - & - \\
\hline \multirow{4}{*}{20.0} & 14 & - & 3.7 & 4.8 & 4.9 & 5.0 & 4.8 \\
\hline & 18 & - & 3.5 & 4.5 & 4.7 & 4.8 & 4.7 \\
\hline & 22 & - & 3.3 & 4.1 & 4.5 & 4.6 & 4.5 \\
\hline & 26 & - & 3.0 & 3.8 & 4.0 & 4.3 & 4.0 \\
\hline \multirow{4}{*}{ 30.0 } & 14 & - & 4.4 & 5.0 & 5.0 & 5.0 & 4.9 \\
\hline & 18 & - & 4.0 & 4.8 & 4.9 & 4.9 & 4.5 \\
\hline & 22 & - & 3.8 & 4.7 & 4.6 & 4.7 & 4.3 \\
\hline & 26 & - & 3.6 & 4.3 & 4.4 & 4.6 & 4.1 \\
\hline \multirow{4}{*}{40.0} & 14 & - & 4.0 & 4.9 & 5.0 & 4.8 & 4.6 \\
\hline & 18 & - & 3.6 & 4.7 & 4.8 & 4.7 & 4.4 \\
\hline & 22 & - & 3.5 & 4.6 & 4.7 & 4.5 & 3.9 \\
\hline & 26 & - & 3.1 & 4.1 & 4.4 & 4.1 & 3.6 \\
\hline \multirow{4}{*}{$\mathbf{5 0 . 0}$} & 14 & - & 3.9 & 3.6 & 3.8 & 3.6 & 3.7 \\
\hline & 18 & - & 3.7 & 3.4 & 3.4 & 3.3 & 2.9 \\
\hline & 22 & - & 3.5 & 3.4 & 3.2 & 3.1 & 2.8 \\
\hline & 26 & - & 2.9 & 3.0 & 3.0 & 2.9 & 2.8 \\
\hline
\end{tabular}

When treating fermented cabbage with ultrasound at a frequency of $20.0 \mathrm{kHz}$, the highest rates are achieved with a processing time of 8 minutes. Moreover, the maximum effect (5.0) while maintaining a 5-point assessment of organoleptic characteristics was observed on the 14th day of product storage. The indices for 12 days decreased, but insignificantly and at the end of the experiment on the 26th day amounted to 4.3 points. Cabbage retained good taste, while the consistency was slightly soft, and the aroma was low [10].

With an increase in the ultrasound frequency to $30.0 \mathrm{kHz}$, the duration of the positive effect depended on the exposure of the treatment. At the same time, the initial indicators on the 14-day storage of products were highest at 4-10 minutes processing. On the 22nd and 26th days, with duration of ultrasonic exposure of 4-10 minutes, the indicators were good and were in the range of 4.1-4.9 points. Thus, the use of ultrasound with a frequency of $30.0 \mathrm{kHz}$ allowed us to preserve the appearance, texture, taste and aroma of fermented cabbage at an excellent level.

Ultrasound lasting 2 minutes, regardless of frequency, did not give positive results at all. This is due to the fact that in such a short time, ultrasound did not have an inhibitory effect on the microflora of fermented cabbage. The activity of living bacteria did not decrease, therefore, the shelf life was not long [10].

The maximum assessment of product quality by organoleptic indicators (5.0 points) was obtained by sonication with a frequency of $30.0 \mathrm{kHz}$ with a processing time of 8 minutes. Appearance, consistency, taste and aroma of fermented cabbage (palatability) did not deteriorate during 26 days of storage.

The minimum assessment of product quality was observed when treating fermented cabbage with ultrasound at $50.0 \mathrm{kHz}$ and the duration of ultrasonic exposure of 6 minutes. So, on the 14th day, organoleptic indicators amounted to 3.6 points, on the 18th day already 3.3 points, on the 22 nd day 3.1 points and on the 26 th day -2.9 points. 
Thus, there is not only a positive effect of ultrasound on the preservation of quality and an increase in the shelf life, but also a negative effect when using high frequencies for a long time. In such cases, there is a deterioration in the consistency and a sharp softening of the tissue of the cabbage [11].

Table 2

\section{Dynamics of acidity changing of fermented cabbage depending on the ultrasonic treatment regime}

\begin{tabular}{|c|c|c|c|c|c|c|c|}
\hline \multirow{2}{*}{$\begin{array}{l}\text { Range of ultrasonic } \\
\text { processing (A), } \mathrm{kHz}\end{array}$} & \multirow[t]{2}{*}{ Termofstorage, day } & \multicolumn{6}{|c|}{ Processing time (B), minutes } \\
\hline & & 0 & 2.0 & 4.0 & 6.0 & 8.0 & 10.0 \\
\hline \multirow{5}{*}{$\begin{array}{l}\text { Control without } \\
\text { processing }\end{array}$} & 14 & 0.8 & - & - & - & - & - \\
\hline & 18 & 1.0 & - & - & - & - & - \\
\hline & 22 & 1.6 & - & - & - & - & - \\
\hline & 26 & 1.8 & - & - & - & - & - \\
\hline & $\begin{array}{c}\text { Change in acidity from } \\
\text { day } 14 \text { to day } 26\end{array}$ & 1.0 & - & - & - & - & - \\
\hline \multirow{5}{*}{20.0} & 14 & - & 0.9 & 0.9 & 0.9 & 0.8 & 0.8 \\
\hline & 18 & - & 1.0 & 1.0 & 1.0 & 1.1 & 0.9 \\
\hline & 22 & - & 1.2 & 1.2 & 1.2 & 1.1 & 1.1 \\
\hline & 26 & - & 1.4 & 1.4 & 1.4 & 1.2 & 1.2 \\
\hline & $\begin{array}{l}\text { Change in acidity from } \\
\text { day } 14 \text { to day } 26\end{array}$ & - & 0.5 & 0.5 & 0.5 & 0.4 & 0.4 \\
\hline \multicolumn{8}{|c|}{$\mathrm{LSD}_{0.05}$ for $\mathrm{A}=0.098 ; \mathrm{B}=$ n.s.; $\mathrm{B} / \mathrm{A}=0.054$} \\
\hline \multirow{5}{*}{30.0} & 14 & - & 0.8 & 0.8 & 0.7 & 0.7 & 0.7 \\
\hline & 18 & - & 1.0 & 0.9 & 0.9 & 0.8 & 0.8 \\
\hline & 22 & - & 1.1 & 1.0 & 1.0 & 0.9 & 0.9 \\
\hline & 26 & - & 1.3 & 1.3 & 1.2 & 1.1 & 1.0 \\
\hline & $\begin{array}{l}\text { Change in acidity from } \\
\text { day } 14 \text { to day } 26\end{array}$ & - & 0.5 & 0.5 & 0.5 & 0.4 & 0.3 \\
\hline \multicolumn{8}{|c|}{$\mathrm{LSD}_{0.05}$ for $\mathrm{A}=0.078 ; \mathrm{B}=0.072 ; \mathrm{B} / \mathrm{A}=0.054$} \\
\hline \multirow{5}{*}{40.0} & 14 & - & 0.9 & 0.9 & 0.9 & 0.8 & 0.8 \\
\hline & 18 & - & 0.9 & 0.9 & 0.9 & 0.9 & 0.8 \\
\hline & 22 & - & 1.0 & 1.0 & 1.0 & 0.9 & 0.9 \\
\hline & 26 & - & 1.3 & 1.2 & 1.2 & 1.1 & 1.0 \\
\hline & $\begin{array}{c}\text { Change in acidity from } \\
\text { day } 14 \text { to day } 26\end{array}$ & - & 0.4 & 0.3 & 0.3 & 0.3 & 0.2 \\
\hline \multicolumn{8}{|c|}{$\mathrm{LSD}_{0.05}$ for $\mathrm{A}=0.098 ; \mathrm{B}=0.084 ; \mathrm{B} / \mathrm{A}=0.096$} \\
\hline \multirow{5}{*}{50.0} & 14 & - & 0.8 & 0.7 & 0.7 & 0.8 & 0.7 \\
\hline & 18 & - & 0.8 & 0.8 & 0.9 & 0.9 & 0.7 \\
\hline & 22 & - & 1.0 & 0.9 & 1.0 & 0.9 & 0.8 \\
\hline & 26 & - & 1.1 & 1.0 & 1.0 & 1.0 & 0.8 \\
\hline & $\begin{array}{l}\text { Change in acidity from } \\
\text { day } 14 \text { to day } 26\end{array}$ & - & 0.3 & 0.3 & 0.3 & 0.2 & 0.1 \\
\hline \multicolumn{8}{|c|}{$\mathrm{LSD}_{0.05}$ for $\mathrm{A}=0.098 ; \mathrm{B}=$ n.s.; $\mathrm{B} / \mathrm{A}=0.054$} \\
\hline
\end{tabular}

n.s. - not significant $(\mathrm{p}=0.05)$

Analyzing the data of Table 2, in the control variant of the study without sonication on the 14th day of storage, the acidity had a reading of $0.8 \%$. By the 26th day, acidity increased by $1.0 \%$ and amounted to $1.8 \%$, which did not meet the requirements of the regulatory document. Such a product is excessively acidic and unsuitable for consumption [12].

At the same time, some dynamics was observed: with an increase in the parameters of the frequency of ultrasonic exposure and duration, acidity does not increase due to a decrease in the activity of lactic acid bacteria. The maximum effect is achieved when exposed to a frequency of 50.0 $\mathrm{kHz}$ with an exposure of 10 minutes. 
Normal acidity is in the range of $0.7-1.5 \%$. The lower this indicator, the better, because with this level of acidity, organoleptic indicators are the best. As the acidity increases, the taste of the product worsens, a pronounced sour taste is felt. All options of cabbage subjected to ultrasonic treatment had indicators that met the requirements of GOST and did not exceed the limits of the normalized acidity index [13].

Thus, we can conclude that the rate of increase in acidity without the use of ultrasound is 2 times faster, and vice versa, with the use of ultrasonic treatment, the process of acid formation slows down, which indicates a weakening of the activity of lactic acid bacteria [14].

\section{Conclusions}

According to the results of the research, the influence of ultrasound on the quality and duration of storage of fermented cabbage became apparent. Optimum ultrasound treatment modes are those in which the effect of ultrasound does not soften the cabbage, but helps increase the shelf life due to the inhibitory effect of fermented products on the microflora, primarily lactic acid bacteria. Such modes are a frequency of $30 \mathrm{kHz}$ with duration of ultrasonic processing of 8 minutes. So, the tasting assessment on the 26th day of storage in this mode was 4.6 points, which is significantly higher than with other processing parameters. The acid indicator of fermented cabbage in this mode on the 26th day had a value of $1.1 \%$, which fully corresponded to the requirements of the standard. Thus, the effectiveness of using ultrasound to increase the shelf life of fermented cabbage is justified.

\section{References}

[1] Врублевская Н. Целительнаясила. Квашеная капуста (Healingpower. Fermented cabbage. The author is compiler N.Vrublevskaya). - M.: KRON-PRESS, 2000.160 p.(In Russian).

[2] Куницына М.Г. Справочник технолога плодоовощного производства (Reference technologist of fruit and vegetable production. Compiled by M.G. Kunitsyna) St. Petersburg: PROFIINFORM, 2004. 480 p.(In Russian).

[3] Гаспарян Ш.В. Инновационные технологии в производстве солено-квашеной продукции (Innovative technologies in the production of salted-fermented products: Monograph): Publishing House of the Russian State Autonomous University-Moscow Agricultural Academy, 2015. 129 p. (In Russian).

[4] Гаспарян Ш.В. Improving the elements of the technology for the manufacture and storage of pickled products: dis. cand. s.-kh. sciences: Moscow, 2013. 116 p. (In Russian).

[5] Сборник технологических инструкций по переработке овощей. (Collection of technological instructions for processing vegetables. Volume 1).-M.: AgroNIITEIPP, 2000.324 p. (In Russian).

[6] Хмелёв В.Н., Попова О.В. Многофункциональные ультразвуковые аппараты и их применение в условиях малыхп роизводств, сельском и домашнем хозяйстве: научнаямонография(Multifunctional ultrasonic devices and their application in small industrial, agricultural and household conditions: scientific monograph) Alt. state tech. un-t them. I.I. Polzunova. Barnaul: Ed. Altai State Technical University, 1997.160p.(In Russian).

[7] Метелица Д.И., Ерёмин А.Н., Потапович М.В. Инактивация и стабилизация ферментов в поле ультразвуковой кавитации (Inactivation and stabilization of enzymes in the field of ultrasonic cavitation). Transactions of Belarusian State University. T.8. Part 1. - Minsk, 2013. pp. 20-44.(In Russian).

[8] Хорбченко И.Г. Звук, ультразвук, инфразвук (Sound, ultrasound, infrasound). M.: Knowledge, 1986.192 p. (In Russian).

[9] КрасильниковВ.А. Звуковые и ультразвуковые волны в воздухе, воде и твердых телах (Sound and ultrasonic waves in air, water and solids. - 3 ed.) - M., 2016.560 p.(In Russian).

[10] Hakobyan B.V., ErshovYu. A. The basics of the interaction of ultrasound with biological objects. - M.: MSTU. Bauman, 2005.224 p.

[11]Данько С.Ф. Интенсификация процесса солодоращения ячменя со звуком различной частоты (The intensification of the process of malting of barley with sound of different frequencies): dis ... cand. tech. sciences. - M.: Russian Academy of Natural Sciences Research Institute of Applied Eurology, 2001. 92 p. (In Russian). 
[12] The development strategy of the food and processing industry of the Russian Federation until 2020/Order of the Government of the Russian Federation of April 17, 2012 No. 559-r

[13]Хоссейни Ф. Интенсификация способов получения чистой культуры хлебоперканыхд рожжей (Intensification of methods for obtaining a pure culture of baking yeast): dis cand. tech. sciences: - M.: MGUPP, 2005.163 p. (In Russian).

[14]Патент №2455086. Способ ультразвуковой кавитационной обработки жидких сред и расположенных в среде объектов (Patent 2455086 - Method for ultrasonic cavitation treatment of liquid media and objects located in the medium). Issued and published 2012. 